\title{
On the Probabilistic Analysis of Precipitating Cells Defined by the Spatial Concentration of Falling Snow Particles
}

\author{
By Yoshio Sasyō and Hiroshi Tokuue \\ Meteorological Research Institute \\ (Manuscript received 28 February 1964)
}

\begin{abstract}
Photographic observations were carried out on the spatial concentration of falling snow particles. Photographs were taken by $8 \mathrm{~mm}$ cine camera at the rate of 16 frames a minute. The main results are described as follows:

1) The frequency of each concentration which is classified by 10-particle difference, was obtained in the shower and continuous types of snowfall. The distribution curve of frequency may be explained from a general compound Poisson's distribution in the case of shower, while it is represented approximately as a Gaussian distribution in the cese of continuous one.

2) In the case of snow shower, the probability density function of cells that their average spatial concentration lies between $\lambda$ and $\lambda+d \lambda$ was obtained, where $\lambda$ is the concentration averaged on each cell. It may be thought that the probability distribution function consists of two curves: one of them has a steeper and larger maximum value than the other one, which may be thought Gaussian distribution in form, at low concentration. This result illustrates that the former corresponds to the distribution curve of original cells and the latter is due to snow particles blown down from neighbouring trees and roofs of huts.

3) Auto-correlations were calculated from the fluctuation of spatial concentration in both cases.
\end{abstract}

\section{Introduction}

The remarkable change of some precipitation, e. g. rainfall intensity, has been usually explained by passage of precipitating cells of various scales, intensities, and so on over an observation point. Many studies on the precipitating cells have been presented but as far as the authors are aware, these studies are generally interesting in their statistical mean dimensions or in their synoptical patterns on the base of mesoanalysis. It is necessary, however, that the conception of precipitating cells must be defined under the physical consideration more useful in the field of cloud physics. From this point, the cells are defined by the spatial concentrations of precipitating particles, and will be discussed as follows.

\section{Procedure of analysis}

As mentioned in Sec. 1, a precipitating phenomenon may be thought to be an assembly of many precipitating cells, and the feature of chronological change of the precipitation depends on the way of passage of various cells. Therefore, it can be thought that some observations of the precipitation corresponds to the sampling from inhomogeneous population in the probability theory.

For probabilistic treatment, it is assumed that the cells are defined by one suitable parameter $\lambda$, averaged on each cell. Let us denote the cell, for which the value of the prameter falls between $\lambda$ and $\lambda+d \lambda$, by $\lambda$-cell.

Now, if a certain observation was made at given time, the probability of the events that the observed value lies between $k$ and $k+\Delta k$ is shown as follows according to probability theory.

$$
\Psi(k) \Delta k=\int_{0}^{\infty} P(k \mid \lambda) \varphi(\lambda) d \lambda \Delta k
$$

where $\Psi(k)$ is the probability density function in question, and $P(k \mid \lambda)$ is the conditional probability function that the observed value 
falls between $k$ and $k+\Delta k$ in $\lambda$-cell, $\varphi(\lambda)$ shows the probability that $\lambda$-cell is passing over the observation point at the given time.

If $\Psi(k)$ and $P(k \mid \lambda)$ are known, it is possible to obtain $\varphi(\lambda)$ as the solution of integral eq. (1), and the characterization of the precipitation system may be made.

Now, if the value $k \sim k+\Delta k$ arises $\nu$ times in the observations of $N$ times, $\Psi(k)$ is defined as follows,

$$
\Psi(k) . \Delta k=\lim _{N \rightarrow \infty} \frac{\nu}{N}
$$

Therefore, it is necessary to carry out numerous observations in order to determine the probability function $\Psi(k)$ accurately. For the observation of spatial concentration of the precipitating particles, we may use a binomial distribution as $P(k \mid \lambda)$. However, Poisson's or Gaussian distribution can be applied practically as an approximation instead of the binominal distribution, since the total number of precipitating particles in the cell is big enough. In other words, if we give our attention to a certain narrow space in the cell, the probability that the number of particles in the narrow space lies between $k$ and $k+\Delta k$ is represented by the binomial distribution: namely

$$
b(k ; n, p)=\left(\begin{array}{l}
n \\
k
\end{array}\right) p^{k} q^{n-k}
$$

where $\left(\begin{array}{l}n \\ k\end{array}\right)=\frac{n !}{k !(n-k) !}$ is well-known as binomial coefficient, $n$ is the total number of particles in the cell, or the number of particles in the partial space large enough to represent the averaged concentration of the cell. $p$ is the probability that an arbitrary particle is contained in the observed narrow space, and $q$ is the complementary probability of $p$, namely

$$
q=1-p
$$

In eq. (3), when $n \rightarrow \infty$ and $n p=\lambda$ remains bounded, we have Poisson's distribution function as

$$
b(k ; n, p) \approx \frac{\lambda^{k}}{k !} e^{-\lambda}
$$

and when $n p \rightarrow \infty$ but $|k-n p| \rightarrow 0$, Gaus- sian distribution is used approximately in eq. (3), namely

$$
\begin{aligned}
b(k ; n, p) \approx(2 \pi n p q)^{-1 ! 2} \\
\cdot \exp \left[-(k-n p)^{2} /(2 n p q)\right]
\end{aligned}
$$

In general, Poisson's distribution has been thought so that it should be applied in "rare events," since when $n \rightarrow \infty, p$ must approach zero in order to hold $\lambda=n p$ at a moderate magnitude. This condition, however, may be also thought that in other words, if $n$ is small, regarding to a small partial space in the cell, $\lambda$ or $p$ depends on $n$ value or the dimension of the partial space. We must, therefore, consider the numerous particles in a fairly large partial space in the cell in order that $\lambda$ or $p$ is independent of the total number $n$ in partial space and the representative parameter of the cell. Thus we may say that the Poisson's distribution is applied in the case of relatively inhomogeneous spatial distribution of precipitating particles. On the other hand, the Gaussian distribution is applied in fairly homogeneous case, since $\lambda$ or $p$ is determined without reference to $n$ value, that is, the characteristic parameter of the cell can be obtained from an arbitrarily narrow space in the cell.

If a precipitation source consists of one kind of population whose averaged concentration is $\lambda_{0}$, the frequency distribution of the observed concentration would be denoted as the Poisson's or Gaussian distribution curve with averaged concentration $\lambda_{0}$, in other words, $\varphi(\lambda)$ in eq. (1) is denoted as follows,

$$
\begin{aligned}
\varphi(\lambda) & =1 & & \lambda=\lambda_{0} \\
& =0 & & \lambda \neq \lambda_{0}
\end{aligned}
$$

However, in most cases, the source of precipitation consists of many various cells or an inhomogeneous layer, therefore, $\varphi(\lambda)$ may be thought as the characteristic parameter of the structure of a precipitation system.

\section{Observational results}

\section{1) The case of snow shower}

The observation of snow shower was made at Gomando Nursery of Takada District Forestly Office in Niigata Prefecture on 16 th and 17th Feb. 1963. The weak snow shower was occurring successively from the early 

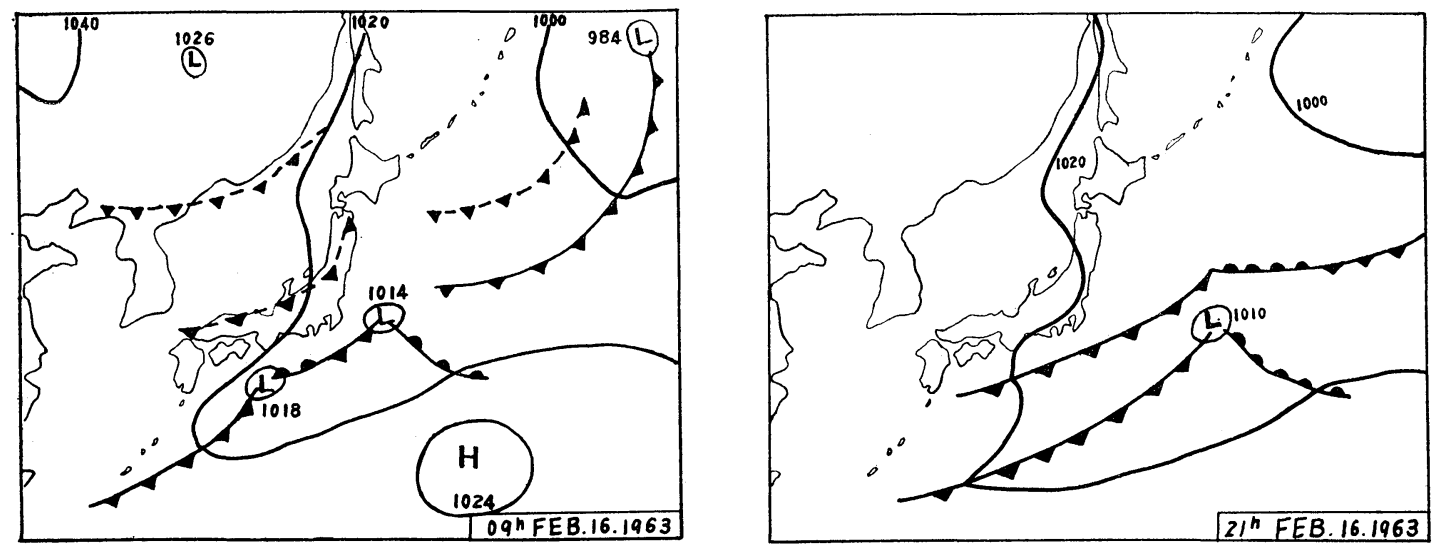

Fig. 1. Surface charts at 0900 and 2100 J.S.T.
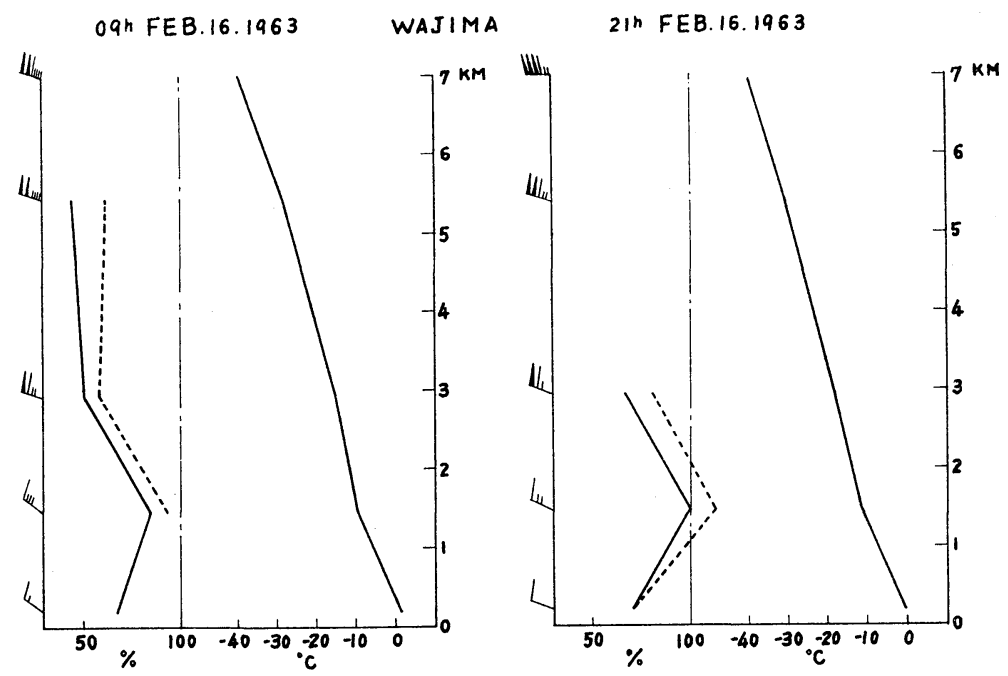

Fig. 2. Sounding curves at Wazima.

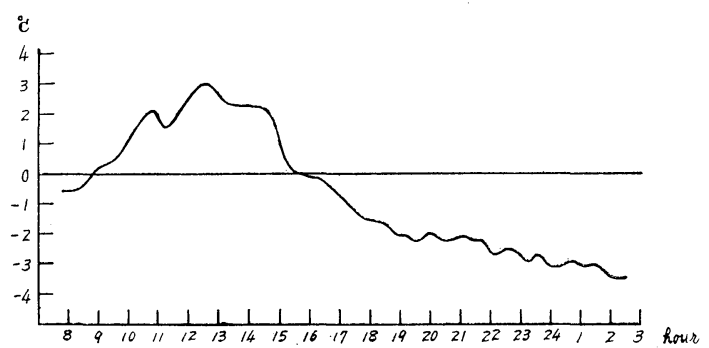

Fig. 3. Surface air temperature at the observation point. 

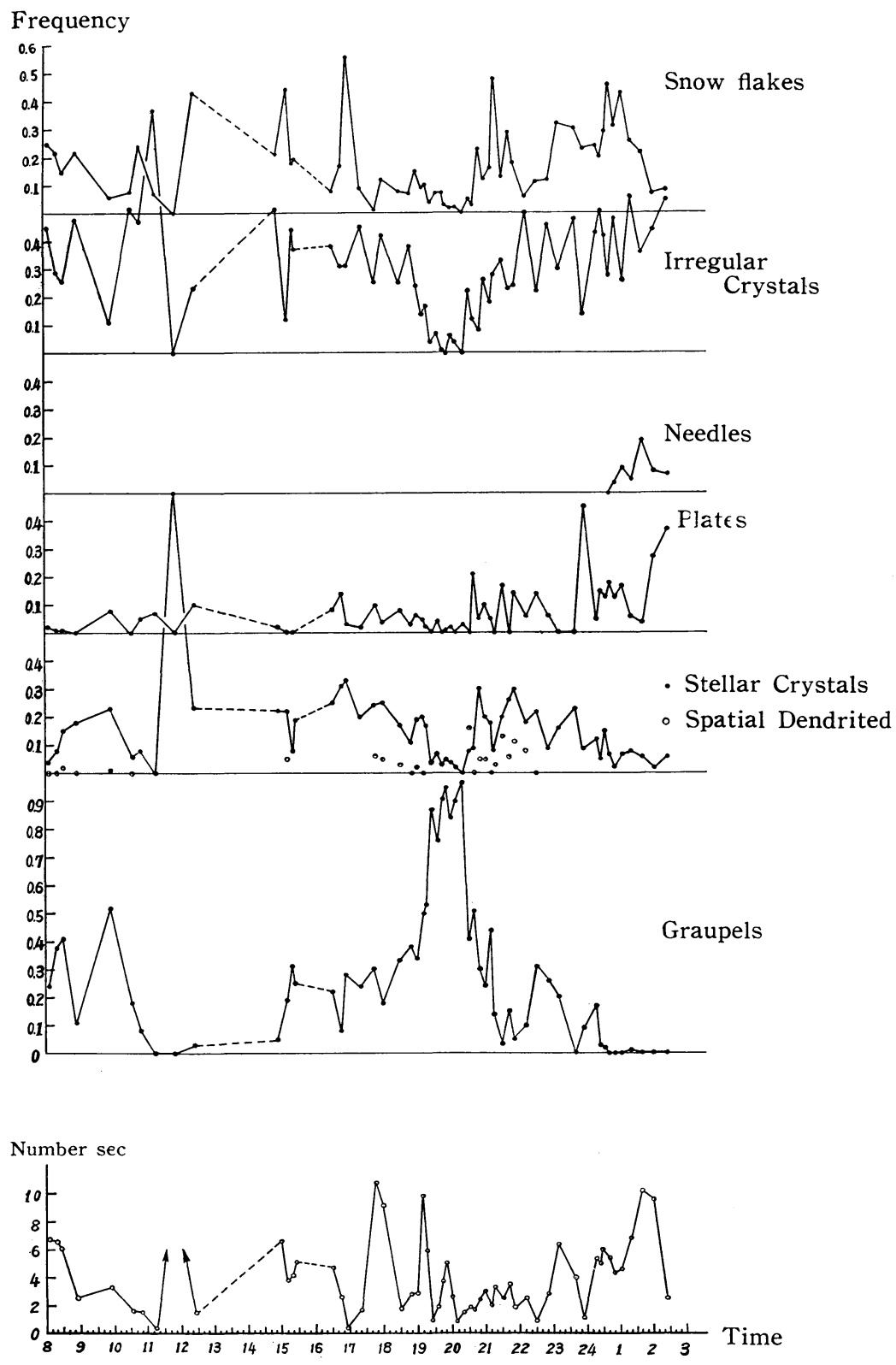

Fig. 4. The chronological change of snow crystals, which were obtained from the plastic replicas. The lowest row represents the number of fallen snow crystals on the blackened bromide per one second.

If the mean fall speed of snow particles are assumed $1.5 \mathrm{~m} \mathrm{sec}^{-1}$ the maximum, and minimum concentrations are estimated about $500 \mathrm{~m}^{-3}$, and $100 \mathrm{~m}^{-3}$.

morning on 16 th till about $0230 \mathrm{~J} . \mathrm{S}$. T. on 17th. The surface weather charts at 0900 and $2100 \mathrm{~J} . \mathrm{S}$. T. on 16 th are shown in Fig. 1. Fig. 2 shows the sounding curves at Wazima observed at 0900 and $2100 \mathrm{~J} . \mathrm{S}$. T. on 16th. In Fig. 2, dotted lines indicate humidities with respect to ice surface, and the wind profiles are shown in the left part of the figure indicating long wings $10 \mathrm{~m} \mathrm{sec}^{-1}$, medium $5 \mathrm{~m} \mathrm{sec}^{-1}$ and short $1 \mathrm{~m} \mathrm{sec}^{-1}$ respectively. According to the sounding curve at 0900 J.S.T., it may be possible to say that the snow crystals 
Graupel

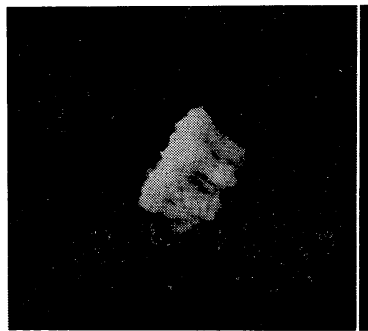

$15 \mathrm{~h} \quad 11 \mathrm{~m} \quad 16$ th

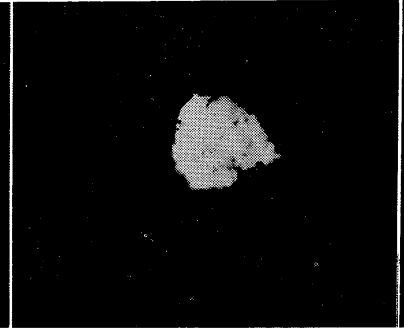

$15 \mathrm{~h} \quad 22 \mathrm{~m} \quad 16$ th

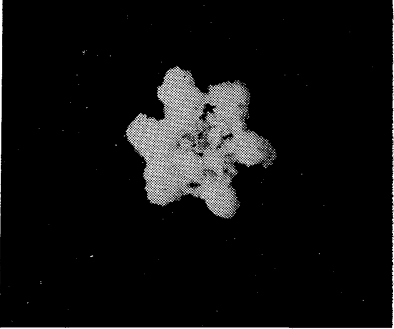

$16 \mathrm{~h} 32 \mathrm{~m} 16 \mathrm{th}$

Stellar

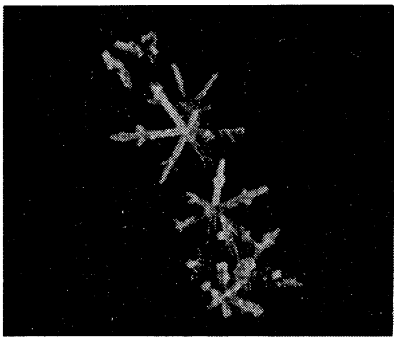

$11 \mathrm{~h} 50 \mathrm{~m} \quad 16$ th

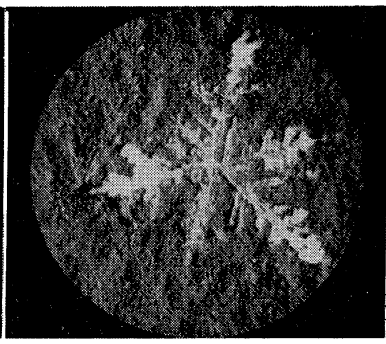

$19 \mathrm{~h} \quad 14 \mathrm{~m} \quad 16$ th

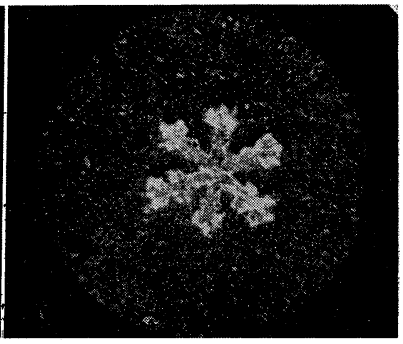

$23 \mathrm{~h} \quad 40 \mathrm{~m} \quad 16 \mathrm{th}$

Plate

Needle

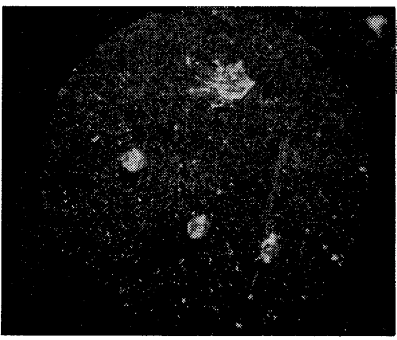

$23 \mathrm{~h} 55 \mathrm{~m} \mathrm{16th*}$

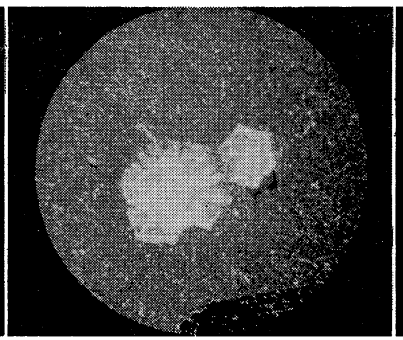

$02 \mathrm{~h} \quad 01 \mathrm{~m} \quad 17 \mathrm{th}$

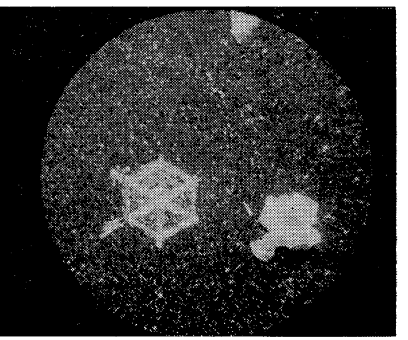

$02 \mathrm{~h} \quad 01 \mathrm{~m} \quad 17 \mathrm{th}$

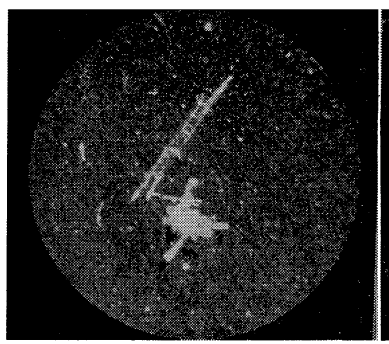

$00 \mathrm{~h} \quad 52 \mathrm{~m} .17 \mathrm{th}$

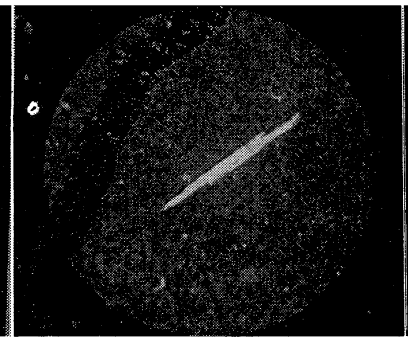

$01 \mathrm{~h} \quad 02 \mathrm{~m} \quad 17 \mathrm{th}$

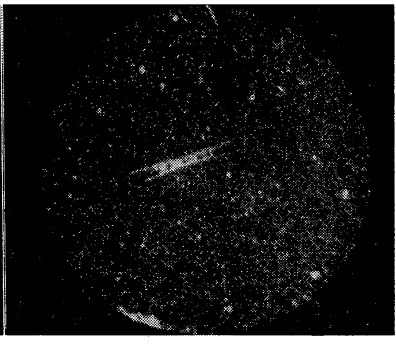

$01 \mathrm{~h} \quad 02 \mathrm{~m} \quad 17$ th

Plate 1. The typical snow crystals on 16 th Feb. 1963 (Niigata). ( $\times 8)$

* The gass-like ice-drops, which are seen in the photograph at $23 \mathrm{~h} 55 \mathrm{~m}$ have been found always in snow by detailed observation of plastic replicas of snow-crystal. (Y. Sasyō, 1958) 
were produced at about $1300 \mathrm{~m}$ level where air temperature and wind velocity are $-15^{\circ} \mathrm{C}$ and $8 \mathrm{~m} \mathrm{sec}^{-1}$ respectively. The surface air temperature is shown in Fig. 3, but is not accurate, because it was measured by thermometer hunged near a drying shelf of plastic replicas under an eaves of the hut. The plastic replicas on $16 \times 12 \mathrm{~cm}^{2}$ bromides blackened through photographic processes were sampled every about 10 minutes. The changes of the snow crystal forms are shown in Fig. 4. The systematic changes of the types of crystals are not shown explicitly in this figure, though the principal types of snow crystals were graupels, stellars (including dendritic crystal) and irregulars. The typical snow crystals are shown in Plate 1.

Graupels decreased gradually in their frequency after $2100 \mathrm{~J} . \mathrm{S}$. T. and then the structure of stellars became simpler forms changing their sizes, while the number of small plates increased relatively. After $0100 \mathrm{~J} . \mathrm{S} . \mathrm{T}$. on 17th the needle-types of crystals appeared for a short period. It is interesting that graupels and dendrites seem to come out simultaneously, this fact may suggest that

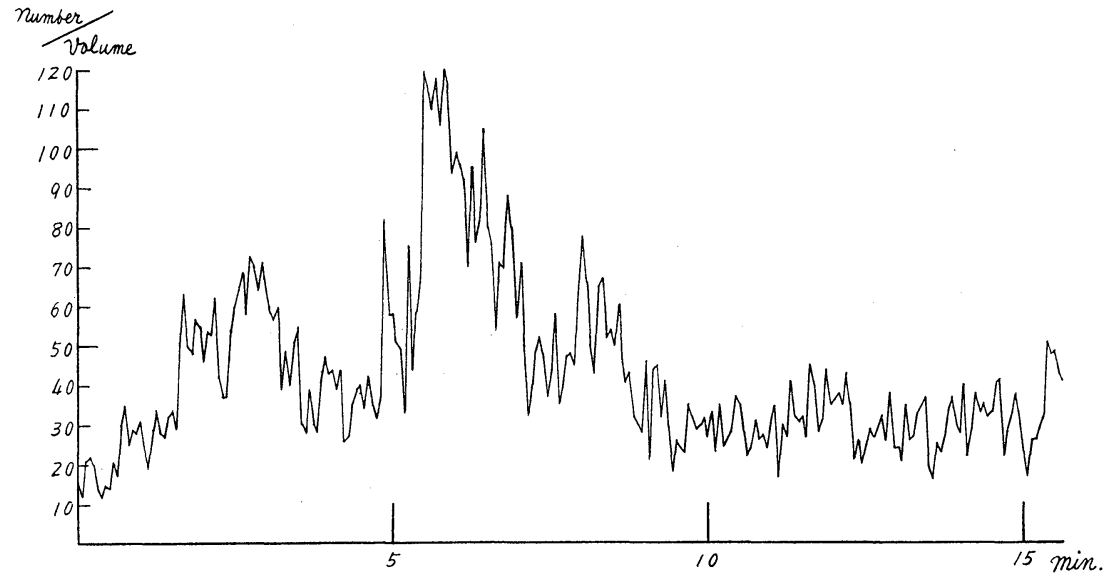

Fig. 5. Partial data of observed spatial concentration of falling snow particles on 16th Feb. 1963 (Niigata).

the graupels originated from spatial dendrites.

The photographs of falling snow crystals were taken by an $8 \mathrm{~mm}$ cine camera with a lense of $40 \mathrm{~mm}$ in focal length at a rate of 16 frames a minute, from 1130 to 1600 J.S.T. on 16th (the net time of operation was about 4 hours). The dark grey wall of the hut, which was about $13 \mathrm{~m}$ far from the camera, was used for a background, for the sake of taking falling snow particles as white streaks. Although the field of vision of the camera was calculated as about, $1 \mathrm{~m}^{3}$, it is not necessary that all snow particles in this field of vision were photographed, since not much consideration has been given to artificial lighting. Therefore, the counted numbers from photographs must be treated as the relative values of concentration. In Fig. 4, the lowest row represents the numbers of fallen snow crystals on the bromide per unit time. Assuming the mean fall speed of snow particles $1.5 \mathrm{~m} \mathrm{sec}^{-1}$,

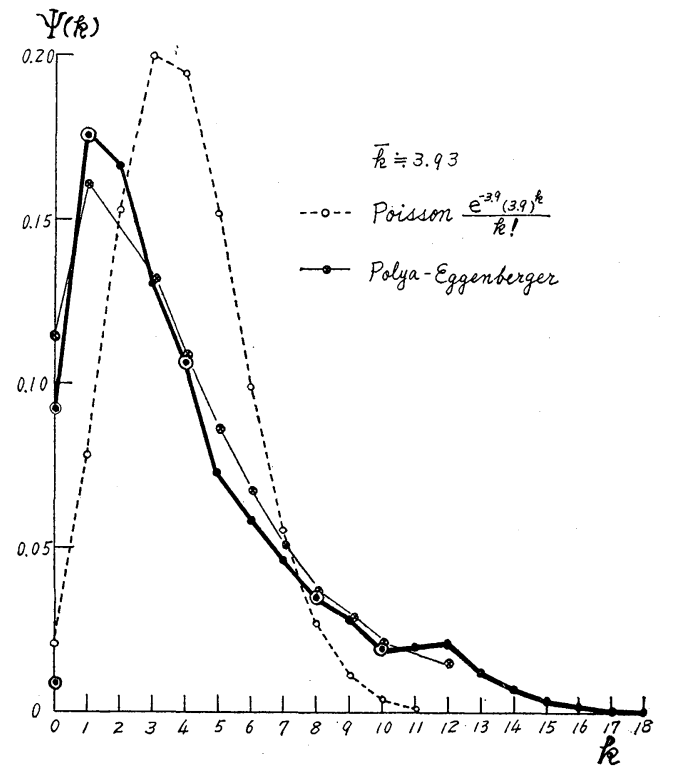

Fig. 6. The frequency of each concentration which is classified by 10 particles. The bold line is the observation curve. 
the maximum and minimum concentrations are estimated about $500 \mathrm{~m}^{-3}$ and $100 \mathrm{~m}^{-3}$ respectively. These values are about three times of the photographic measurement.

The partial data of observed spatial concentration of falling snow particles are shown in Fig. 5. The chronological variations of concentration consist of the relatively long periodical changes and sudden fluctuation arises at every observation; the former corresponds to the inhomogenuity of precipitating system or the population, and the latter may be thought to be statistical fluctuation owing to observation in narrow limited space in the cell.

The frequency of each concentration classified by 10 -particle difference, is shown by a bold line in Fig. 6, and the mean concentration is calculated 3.39 from this classification. The Poisson's and Polya-Eggenberger's distribution curves with the same mean value and corresponding contagious constant are shown by dotted and fine solid lines respectively.

The maximum frequency appears at smaller concentration than the mean value. This tendency suggests that the observations has been made in an inhomogeneous population.

As mentioned in Sec. 2, we are able to consider $\Psi(k)$ and $P(k \mid \lambda)$ in eq. (1) to be the frequency distribution in Fig. 6, and the Poisson's distribution respectively.

Putting

$$
\varphi(\lambda) d \lambda=e^{-\lambda / b} \sum_{j=1} A_{j}\left(\frac{\lambda}{b}\right)^{j} d\left(\frac{\lambda}{b}\right)
$$

eq. (1) is written

$$
\Psi(k) \Delta k=\frac{b^{k}}{k !} \frac{1}{(1+b)^{k+2}} \sum_{j=1} A_{j} \frac{(b+j) !}{(b+1)^{j-1}} \Delta k
$$

Now in eq. (8), we ought to determine $A_{j}$ and $b$ so that $\Psi(k)$ may coincide with the value of the observed frequency distribution in Fig. 6. For simplicity, $\varphi(\lambda)$ or $A_{j}$ and $b$ will be calculated in such a way that $\Psi(k)$ is made to coincide with the distribution in Fig. 6 at $k=0,1,4,8$, and 10 (these points are denoted by double circles in Fig. 6). Consequently eq. (8) can be seen the simultaneous linear equations of the five variables with respect to $A_{j}(j=1,2, \cdots 5$, ), and $\varphi(\lambda)$ or $A_{j}$ is solved as function of $b$. Moreover $b$ is able to be determined from the normarized condition of $\varphi(\lambda)$, i.e.

$$
\int_{0}^{\infty} \varphi(\lambda) d \lambda=1
$$

The left hand of eq. (9) was calculated for the function $\varphi(\lambda)$ of which some arbitrary $b$ values were given, and we chose the $b$-value most suitable to eq. (9), since it is no easy to find $b$-value explicitly. For example, putting $b=0.8$ and $b=1.0$, the integral of eq. (9) is estimated 0.78 and 1.14 respectively and so we may put $b=1.0$.

As the final result, $\varphi(\lambda)$ is written as follows,

$$
\begin{aligned}
\varphi(\lambda) d \lambda & =\left(-0.2257 \lambda+0.5474 \lambda^{2}-0.2060 \lambda^{3}\right. \\
& \left.+0.0272 \lambda^{4}\right) e^{-\lambda} d \lambda
\end{aligned}
$$

Eq. (10) is shown graphically in Fig. 7. As was seen in Fig. 7, this distribution curve may be separated two into curves, one of them has a steeper and larger maximum value at low concentration than the other, which may be thought as Gaussian distribution curve in form.

We may consider that the former corresponds to the distribution curve of original cell and the latter is due to snow particles flown down from neighboring trees and huts.

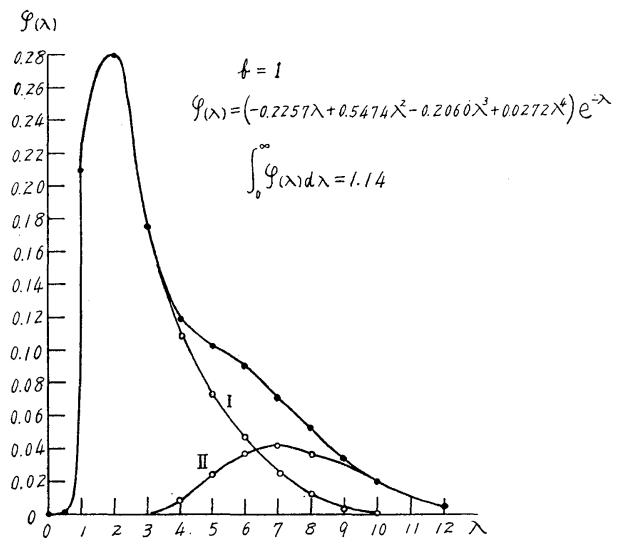

Fig. 7. The probability density function when $\lambda$-cell is passing by the observation point at given time.

\section{2) The case of continuous snow}

The same photographic observations were carried out on the continuous snow at the 
roof of Nakano Branch of Meteorological Research Institute on March 9th 1963. The operation time was during from about 0900 to $1130 \mathrm{~J} . \mathrm{S}$. T. but the duration which is able to analyse was about 25 minutes, because the snow changed to the rain state after about 0930 J.S. T.

The type of snow crystals was half melting needle (Plate 2), and their sizes are about $1 \sim 1.5 \mathrm{~mm}$ in length. The surface weather chart and sounding curve are shown in Figs. 8 and 9. From Fig. 9 the source of snow may be thought about $1500 \sim 2000 \mathrm{~m}$ in height, and the temperature and wind speed was $-8^{\circ} \mathrm{C}$ and $3 \mathrm{~m} \mathrm{sec}^{-1}$ respectively.

The fluctuation of concentration and its frequency are shown in Figs. 10 and 11 respectively. As is seen in Fig. 11, the frequency distribution curve is the same with Gaussian distribution in form substantially, and so in this

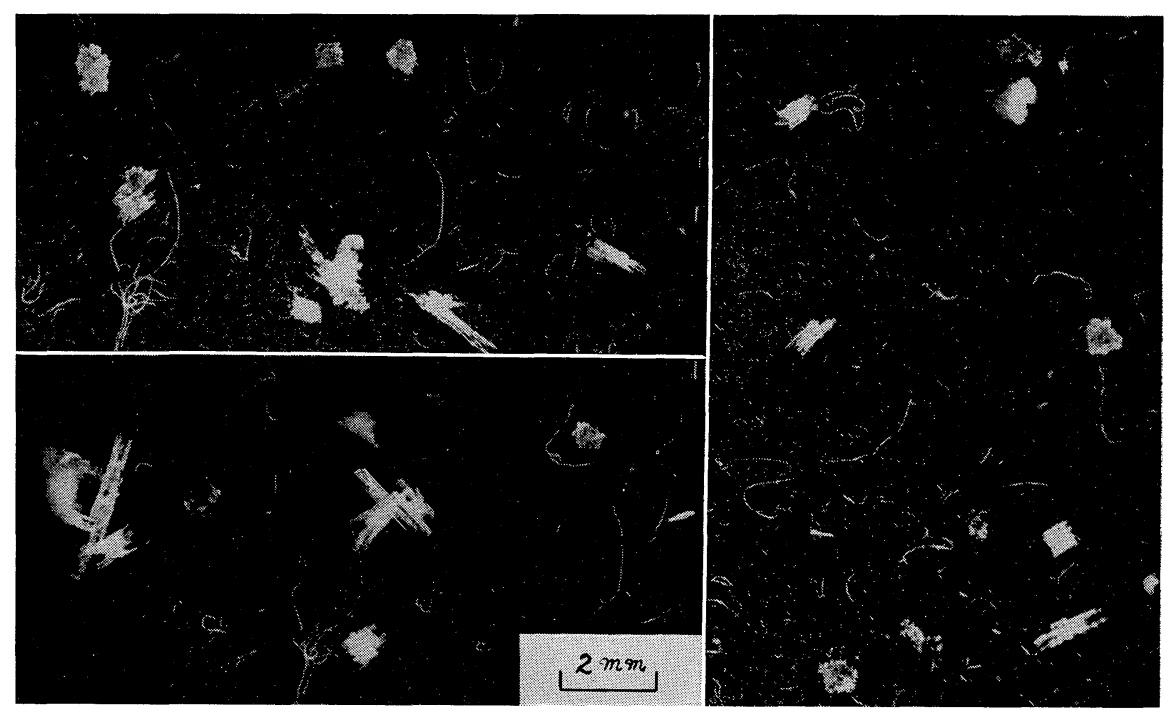

Plate 2. The form of snow crystals on 9th March 1963 (Tokyō).

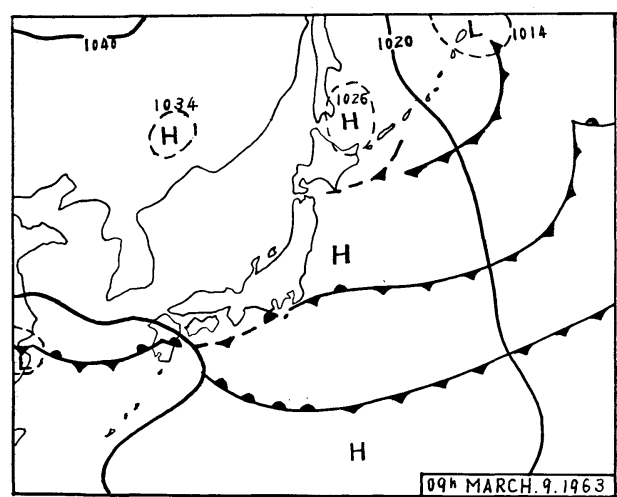

Fig. 8. The surface chart at 0900 J.S. T. March 9th, 1963.

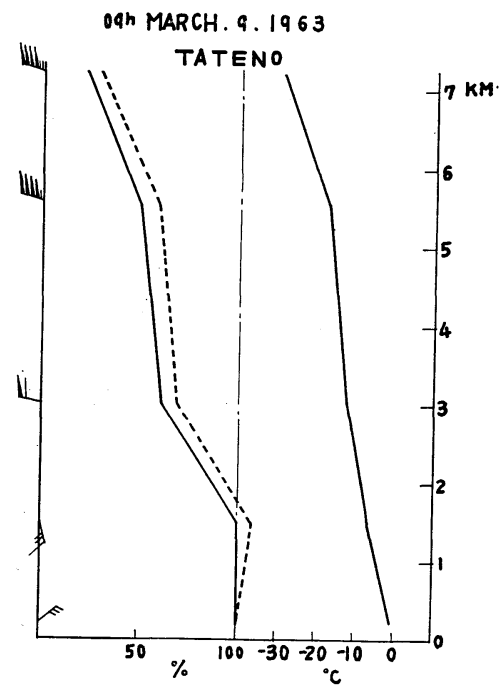

Fig. 9. The sounding curve at Tateno. 


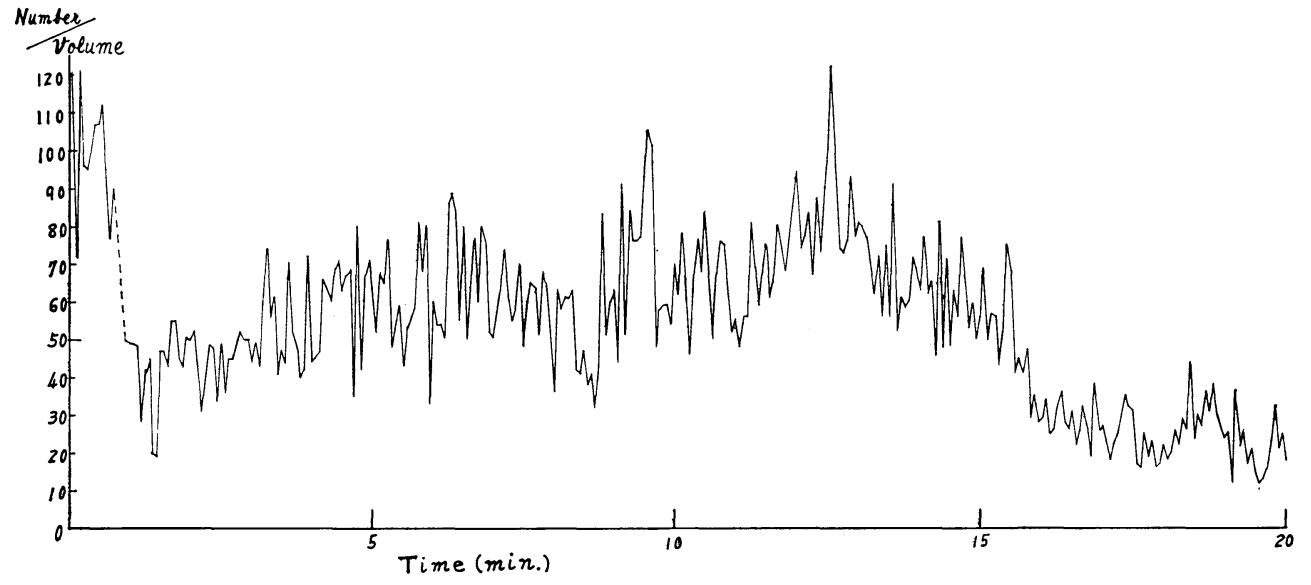

Fig. 10. The partial data of observed spatial concentration of falling snow particles on 9th March 1963 (Toky $\overline{0}$ ). In this figure, snow changed to the rain state after 15 min and the mean spatial concentration reduced to about one-third.

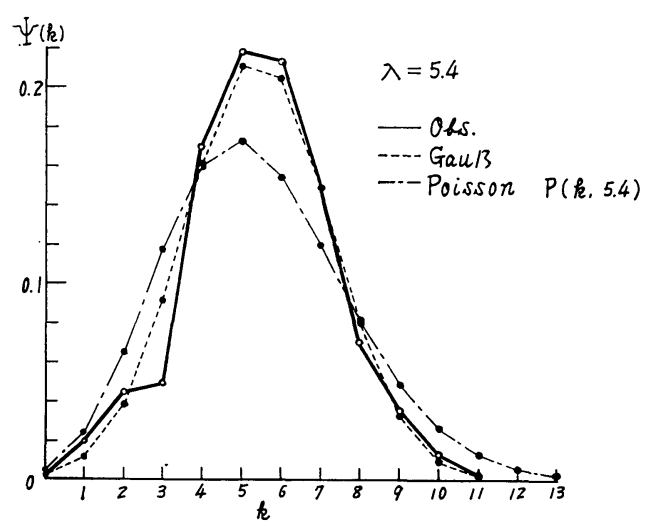

Fig. 11. The frequency distribution of each concentration which is classified by 10-particle difference on 9th Mar. 1963 (Tokyō).

case the source of snow may be considered that it is not the cellular structure but a considerably homogeneous layer.

\section{Mean spatial dimensions of the cells}

It is the interesting problem to research the probability distribution function of the spatial scales of the cells, but this problem is too difficult for us to solve at present, so that we are obliged to seek the mean scale from autocorrelation. Following the usual procedure, the auto-correlations were calculated in both snow cases. They are shown graphically in Figs. 12 13. From these figures, the auto-

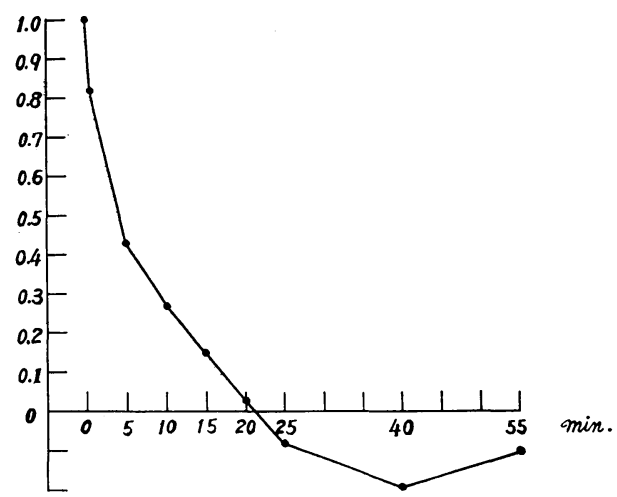

Fig. 12. The auto-correlation in the case of snow shower on 16th Feb. 1963 (Niigata).

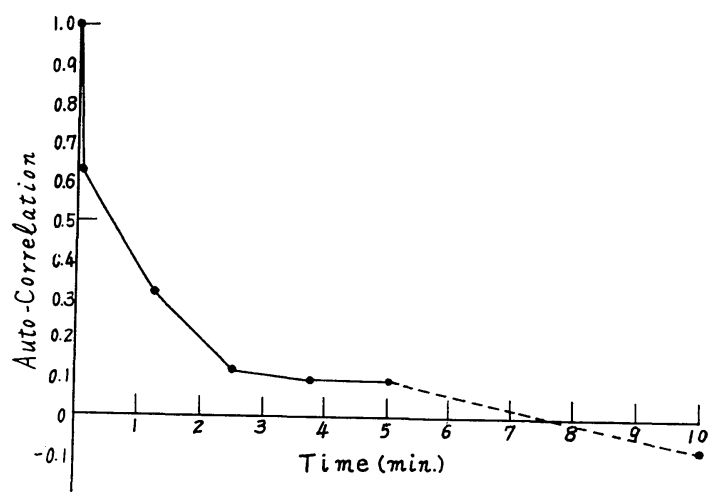

Fig. 13. The auto-correlation in the continuous snow, on 9th Mar. 1963 (Tokyō). 
correlation becomes zero after about 22 minutes in the shower snow and about 8 minutes in the continuous snow. It is strange that the auto-correlation in the continuous snow becomes zero in a shorter period as compared with the shower one. It is difficult to explain the discrepant circumstance but one of the effective causes perhaps may come from the difference of the observation period in both cases.

\section{Discussion}

In the field of cloud physics, we have resolved the precipitation phenomena into the elementary processes and made investigations on these processes under simple assumptions. However, actual precipitation phenomena are very intricated problems, furthermore our observations are carried out usually in narrow limited space in comparision with the scale that will be fully representative of the character of the phenomena, therefore, the observations are accompanied usually by fluctuation. Of course, the fluctuation may be out of the question as long as our investigation is made in the average sense but it is necessary for more accurate descriptions of the phenomena to discuss exclusively of the fluctuation.

From these stand points, precipitation phenomena are not merely physical problem but they might be treated entirely from the statistical physics or probability theory. Therefore, the description of the phenomena should be made by statistical or probabilistic senses.
We cannot determine the governing factors of the distribution curve of spatial concentration, but these may be thought to be concerned with the character of the precipitation system, i.e., the pattern of up-current in the precipitation system, the degree of supplied nuclei, the spatial dimension of the cells, and so on.

It is necessary for full descriptions of precipitation system to make the similar statistical analyses for the other physical parameters, for examples, the size distribution of precipitation elements, precipitation intensity, the spatial dimension of the passing precipitation cells and so on.

\section{Acknowledgement}

In this paper, we would like to thank Dr. Y. Takahashi, Chief Researcher of Physical Meteorology, Meteorological Research Institute, Dr. I. Imai, Chief Researcher and Mr. Fujiwara of Typhoon Research, Meteorological Research Institute, for valuable discussions, also Mr. Koziro Yamagishi, Director of Takada Weather Observatory and Mr. Gentoku Nigorikawa, Gomand Nursery in Takada District Forestly Office, for thinking care of many troubles in observations.

\section{Reference}

Sasyō, Y. (1958): Some studies of the ice pellet. Pap. Met. Geophys., 8, 271-281.

\title{
降雪粒子の空間密度変動よりみた降雪 cell の確率論的解析
}

\author{
佐 粧 純男 - 徳植弘 \\ (気象研究所)
}

降留 cell を次の仮定のあとに磪率論的飞解析した。

1）降水現象の变動は観測点を次々飞通る，いろいろな cell 飞よって起こされる。

2) この cell は, cell 飞付随した任意の物理䁷の各 cell ごとの平妇値入をパラメーターとして規定される。 従って任意時刻飞観測值が $k \sim k+\Delta k$ 内飞入る確率 $\Psi(k) \Delta k$ は

$$
\Psi(k) \Delta k=\int_{0}^{\infty} P(k \mid \lambda) \varphi(\lambda) d \lambda \Delta k
$$

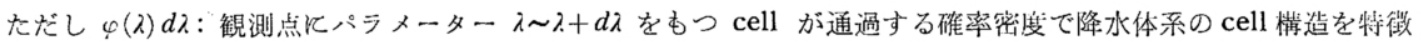


づけるあのである。

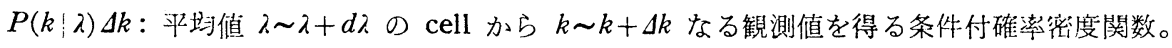

今 $(1)$ 式飞扔いて， $\Psi(k)$ と $P(k \mid \lambda)$ を知れほ $\varphi(\lambda)$ は (1) 式の積分方程式の解として求まり, 降水体系の特㬴 が記述できたことになる。cell を規定する物理量として，降水粒子の空間密度をとれば， $P(k \mid \lambda)$ は二項分布にな り， $\Psi(k)$ は十分多くの観測から作った降水粒子の空間密度の度数分布で近似されよう。この意味で 1963 年 2 月 $1 \epsilon$

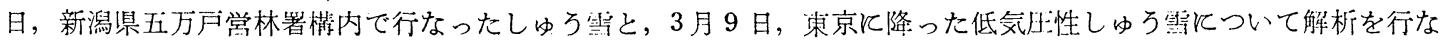
った結果，

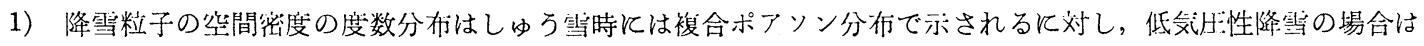
Gauss 分布が適合し，前者の降水体系は非均一性な降等 cell からなり後者は均一な降水源から成ることを澥示して いる。

2) しゅう雪時に招ける $\varphi(\lambda) d \lambda$ を求めた結果は第 7 図のと扣りとなり，2つの曲線の合成から成ると考元られ る。すなわち $1 つ は \lambda=2$ 亿鋭い極大をもつものと他は $\lambda=7$ 位滘大をもつほとんど Gauss 分布と見られる曲線 である。怙とらく前者が本来の cell 飞対応するもので, 後者は飛雪によるものと思われる。

3）降雪粒子の密度変動より自己相関係数を求めた結果, しゅう雪時は 22 分, 低気圧性降雪時は 8 分で無相関に なった。ただし観測時間は, 前者は 4 時間, 後者は 25 分であった。 